\title{
Migrant labor and wear-out in manual sugarcane harvesting in São Paulo, Brazil
}

\author{
Trabalho e desgaste de migrantes no corte manual \\ de cana de açúcar no Estado de São Paulo, Brasil
}

\begin{abstract}
Verônica Gronau Luz ${ }^{1}$
Heleno Rodrigues Corrêa Filho ${ }^{1}$

Alessandro José Nunes da Silva ${ }^{2}$

Erivelton Fontana de Laat ${ }^{3}$

Rodolfo Andrade de Gouveia Vilela ${ }^{4}$

Fernando Oliveira Catanho da Silva ${ }^{5}$

Lia Thieme Oikawa Zangirolani ${ }^{6}$
\end{abstract}

${ }^{1}$ Departamento de Saúde Coletiva, Faculdade de Ciências Médicas,

Universidade Estadual de Campinas. Rua Tessalia

Vieira de Camargo 126, Cidade Universitária

Zeferino Vaz. 13083-887

Campinas SP.

veronicaluz@uol.com.br

${ }^{2}$ Centro de Referência e

Saúde do Trabalhador,

Piracicaba.

${ }^{3}$ Departamento de Educação

Física, Universidade

Estadual do Centro Oeste.

${ }^{4}$ Departamento de Saúde

Ambiental, Universidade de

São Paulo.

${ }^{5}$ Departamento de

Bioquímica, Universidade

Estadual de Campinas.

${ }^{6}$ Departamento de Saúde,

Clínica e Instituições,

Universidade Federal de São

Paulo

\begin{abstract}
The scope of this paper is to describe the work of manual sugarcane harvesters, assessing the nutritional behavior and body composition between the beginning and the end of the harvest. A descriptive longitudinal study was made of harvesters in Piracicaba, São Paulo, Brazil, who answered a socio-demographic questionnaire and authorized measurement of Body Mass Index, Body Fat Percentage and Arm Muscle Circumference at three stages. Creatine kinase on the skeletal isoform, $C$-reactive protein and plasma urea were measured at the end of the harvest. Thirty male migrant harvesters with ages ranging from 18 to 44 from the Northeast (Ceará) were as sessed over a nine-month period. The workers suffered significant body fat and weight loss in the first half of the harvest. Eighteen workers had abnormal levels of creatine kinase and four-out of 24 who had donated blood - had altered urea levels. Sugarcane harvesting work causes weight and body fat loss and gains in the lean body mass index, which suffers wear-out when working on consecutive harvests. It can also cause changes in biochemical markers of chronic systemic inflammation. Further studies will make it possible to comprehend the relationships between stress, wear-out, labor longevity and health in sugarcane harvesting.
\end{abstract}

Key words Occupational health, Nutritional assessment, Anthropometrics, Working conditions
Resumo Descrever o trabalho de cortadores manuais de cana de açúcar avaliando o comportamento nutricional e a composição corporal do início ao final da safra. Estudo descritivo longitudinal de cortadores na região de Piracicaba, São Paulo, Brasil, por meio de um questionário sociodemográfico e antropométrico que permitiu medir Indice de Massa Corporal, Percentual de Gordura Corporal e Circunferência Muscular do Braço em três momentos. Ao final da safra foi dosada a Creatina Quinase na isoforma esquelética, proteina $C$ reativa e ureia plasmática. Durante nove meses, 30 homens safristas migrantes nordestinos (Ceará), com idade de 18 a 44 anos foram estudados. Os trabalhadores tiveram perda significativa de gordura corporal e peso na primeira metade da safra. A maioria ganhou massa magra e os mais velhos na atividade ganharam menos. Dezoito trabalhadores apresentaram valores alterados de Creatina Quinase e quatro tiveram uréia alterada dentre os 24 que cederam sangue. O trabalho no corte de cana gera perda de peso e gordura corporal e aumento de massa magra que se desgasta com a história de trabalho em safras sucessivas. Pode ainda causar alteração de marcadores bioquímicos de inflamação crônica sistêmica. Novos estudos permitirão entender a relação esforço, desgaste, longevidade laboral e saúde no corte de cana.

Palavras-chave Saúde do trabalhador, Estado nutricional, Antropometria, Condições de trabalho 


\section{Introduction}

The search for alternative and renewable fuels such as agro-fuels is due to the negative impact of fossil fuels on the environment and public health. Ethanol has gained prominence because its production and consumption means lower emissions of greenhouse gases (GHG), especially $\mathrm{CO}_{2}$, besides being a fuel that is recycled into the atmosphere through photosynthesis, unlike petroleum-based fuels ${ }^{1}$.

Ethanol is produced by fermentation of agricultural products such as sugarcane, corn, wheat, cassava, sweet potato, among others. Brazil is the largest producer of sugarcane ethanol in the world, while the United States is the largest producer of ethanol, using corn as the primary source. In 2007, the United States and Brazil produced 46 billion liters of ethanol altogether (respectively 26 and 20 billion liters $)^{2}$, which rose to approximately 70 billion liters in $2009^{3,4}$.

Since 1931, Brazil has been using ethanol as fuel for vehicles, but in 1975, with Pro-Alcohol, its use was intensified with the goal of reducing oil importation and increasing the national production of ethanol from sugarcane ${ }^{5}$. However, only in 2003 the first cars using flex fuel technology were manufactured, i.e., flexible to gasoline (with addition of 20 to $25 \%$ of alcohol in its composition - E-20 to E-25) or pure ethanol (E-100), or both $^{6}$, increasing the fleet of all passenger vehicle production from $2.6 \%$ in 2003 to $78.4 \%$ in $2009^{7}$.

Within this context of Brazilian skyrocketing demand for ethanol, later reaching international proportions with exportations especially to the Netherlands, Jamaica and India ${ }^{8}$, there was an increase in the agricultural production of sugarcane, making São Paulo the largest producing state of Brazil, responsible for approximately $60 \%$ of all national production in $2007^{2}$. The need for manpower was expanded concomitantly with the increase in work intensity from such population of sugarcane harvesters.

Brazil has undergone major transformations in the agro-industrial sector, more specifically from the 1980s, which generated employment growth. This growth has intensified the use of manpower, increased working hours and set up payment per production ${ }^{9}$, the latter started to be applied in $1986^{10}$. However, this type of payment began to generate a tremendous demand of resistance and physical effort, which is often far greater than the worker's physical preparation for the activity ${ }^{11}$. In the 80 s, a sugarcane harvester in Brazil used to cut four tons a day. That figure rose to eight tons in the year of 1990 and today the average individual cut is of twelve tons per day ${ }^{12}$.

For this reason and the consequent change in working conditions, in recent years the number of deaths and health problems from these workers has increased. Between the harvests of 2004 and 2007, the deaths of 21 sugarcane hand-harvesters, at work, have been reported in the interior of São Paulo. Among the deaths, there were young workers aged between 24 and 50 - and migrants from other regions of the country, especially from the Northeast ${ }^{13,14}$.

Working conditions for sugarcane harvesting are formed primarily by three elements: production process, work process and forms of payment, which can explain the impact on the workers' health on the sugarcane field ${ }^{12}$.

Describing the work process can clarify the need for enough quantitative and qualitative manpower, in order to define the profile of workers to be hired, mostly young men and migrants. The preference of the mills for hiring migrants instead of local workers is mainly due to cheap labor and greater personal engagement in the work under such conditions. The submission to the demands required for the job is generated by a constant process of expulsion from their home regions, as well by the responsibility for family subsistence and impossibility of failure, since they are the heads of families ${ }^{11}$.

Since 1970, the sugarcane cutting process in Brazil consists of the harvest of the so called "land parcel". This space is where sugar cane cutting is basically formed by a rectangle of 8.5 meters ( 28 feet), which is present in 5 rows of sugarcane, with 1.5 meters between one row and the next. The length of this road varies with the pace and physical strength of each worker. The length of the land parcel will indicate the daily gain of the cane cutters, since it is measured in linear meters and multiplied by the value of the meter ${ }^{12}$.

Besides the amount to be cut, quality is required from the worker. The cane must be cut very close to the ground because the highest concentration of sucrose is on the basis of the plant. However, the cut along the ground must not reach the root to avoid hindering - regrowth ${ }^{12}$.

The physical movement inherent to the task can be an important grievance to health, since the size of the sugar cane work cycle added to the average time for each operation that compose the whole cycle takes 5.6 seconds, including: holding the cane, cutting and throwing the cane into the center of the fields, then going back to the 
initial position ${ }^{13}$. This short period of time and repetition throughout the day represent risk of osteoarticular lesions, since studies point out that there is a risk when the cycles are shorter than 30 seconds ${ }^{15}$. In order to finish the task, the already cut sugar cane positioned at the center of the fields is also blunted (removal of the straw tip), through sequential strokes, requiring a constant flexion of the spine until reaching the end of the land parcel ${ }^{16}$. In Brazil, as well as in several other places in the world, for example South Africa and Guyana, fatigue caused by overwork is a general concern about these workers' health ${ }^{17}$.

Another problem inherent to operating in Brazil is the high temperature, which happen almost every year, considering that sugarcane harvest usually lasts for about nine or ten months (usually from April to December). According to the room temperature pilot study performed with the same group of workers, through checking it daily throughout the working day, using Wet Bulb Globe Temperature - WBGT, maximum temperatures of $27.9^{\circ} \mathrm{C}$, at $14: 00$ p.m. were hit in May (autumn in the country) ${ }^{13}$. According to the Regulatory Standard n.15 Ministry of Labor and Employment ${ }^{18}$, this is set for an activity considered heavy - as it is in the case of sugarcane cutting - the ceiling of the WBGT is $25.0^{\circ} \mathrm{C}$, when measures such as hydration, rest break in the shade must be adopted, among others. For values of WBGT between $26.0^{\circ} \mathrm{C}$ and $27.9^{\circ} \mathrm{C}$, NR n. 15 provides a scheme of 30 -minute work for 30 minutes - rest. On the other hand, the American Conference of Governmental Industrial Hygienists ${ }^{19}$ defines, for activities that require closed clothing and heavy equipment protection (gloves, hoses, leggings, foreign legion cap, hat and pants), as the case with these workers, the decrease of $2^{\circ} \mathrm{C}$ from the maximum threshold of WBGT. Thus one must consider $23.0^{\circ} \mathrm{C}$ the maximum limit of sun exposure.

Considering all the above problems inherent to the activity of - manual sugarcane harvest and the increasing problems created by burning the cane straw before harvesting, more importance was given to the possibility of mechanized harvesting. However, Brazil is geographically composed of different soil types and terrains, and some of them are very steep, where mechanization is not feasible, which means - the hard work of harvesting will have to endure, regardless of the presence of machinery in the sugarcane fields. In the State of São Paulo the Law n. 11.241, of September 19, 2002, was approved regarding the gradual elimination of sugarcane burning: until
2021 in mechanizable areas and in non-mechanizable areas by 2031. Therefore, manual harvesting work shall continue, at least, until these dates ${ }^{20}$.

There are several possible ways to understand physical wear-out, either caused by work or sports activities. Among them, there is the anthropometric assessment, which is the cheapest and least invasive technique, - capable of identifying the nutritional status, health and performance of population $\mathrm{s}^{21}$. Another way to understand - exhaustion is by a biochemical way, through blood tests, that may identify micro damage and inflammation at a cellular level ${ }^{22,23}$.

The aim of this study is to characterize the working conditions of migrant sugarcane harvesters and evaluate- their body composition from - early to late stages of sugarcane harvest in Piracicaba, São Paulo.

\section{Methods}

\section{Sample selection}

The region of Piracicaba was chosen due to the existence of large and most productive sugarcane mills in the State of São Paulo, which produce both sugar and ethanol. The feasibility of field research had several unsuccessful attempts, since the people in charge of the mills had denied the request several times. However, this study was made possible through the inter-institutional articulation promoted by the Worker's Health Reference Center of Piracicaba with the Ministry of Labor and Employment and the Ministry of Labor, which contacted one of the companies audited by the Ministry of Labor and Employment and it had no choice but to agree with the research. This limitation and difficulty of access to the field resulted in a convenience sampling, with access permission granted by a rural sugarcane contractor in the municipality of Elias Fausto, Piracicaba region, State of São Paulo, Brazil. The study was carried out during the 2007/2008 harvest seasons and joined the Project for Research on Public Policy entitled "Inter-institutional action for diagnosis and prevention of occupational accidents: an enhancement proposal for the region of Piracicaba", approved by Fapesp, and had the support of institutions, unions and universities. The project aimed to understand the working conditions of sugarcane manual harvesters, upon the occurrence of deaths in sugarcane fields, in those years.

This is a descriptive longitudinal study of a group of sugarcane manual harvesters. For this 
study, one out of the 36 groups of workers from the enterprise was randomly chosen. Each group consists of 40 workers usually from the same region or city. They have a leader and a bus driver who also assist in the logistical support to the team such as water supply, sanitary installation in a sugarcane field, - transportation of tools and measurement of the output by the end of the day. Teams work independently from each others, there is no contact between them during the season. Given the logistics of cutting cane and the previously negotiated permission, there was no alternative other than monitoring a full team of 40 workers. The entire group was composed of migrants from the State of Ceará (Northeast Brazil), who had a formal contract after three months of experience. They worked on a journey of five labor days for one day of rest and were housed in temporary houses organized by the employer (an average of 8-10 people per house) and received lunch and dinner boxes, supplied by the company itself, and any other meals were provided by themselves. The cost of both food and housing were deducted from the total salary as payment.

Workers who agreed to participate in the study were evaluated at two locations, namely: the housings where they lived, on rest days; and the workplace - sugarcane fields. Assessment periods were: days off, during breaks and lunch time, in three different moments of the harvesting season, considering beginning (June), middle (September) and end (November).

\section{Anthropometric Measurements}

Participants were evaluated at three time monitoring and classification of anthropometric markers. These included body weight $\dagger(\mathrm{kg})$, height $(\mathrm{m})$, body mass index - BMI $\left(\mathrm{kg} / \mathrm{m}^{2}\right)$ $\left(\mathrm{BMI}=\right.$ weight $/$ height $\left.^{2}\right)$ and skinfold measurements (mm) like triceps (TS), supra-abdominal and calf skinfold thicknesses, and arm circumference $(\mathrm{AC})(\mathrm{cm})$. The parameter proposed by Petroski ${ }^{24}$ was used as reference for classifying the percentage of body fat $(\% \mathrm{BF})$, which uses a specific equation for men between 18 and 60 years old, involving these four folds.

The skinfolds were measured using a Lange skinfold caliper, accurate to one millimeter. All locations of anthropometric measures were identified and marked, performing three consecutive measurements of each chosen fold, to minimize the variability between them, as recommended by Costa ${ }^{25}$. Among them, the mean value chosen was the one with minor variations of $5 \%$. Measurements were made by a single researcher specialized in the area in order to improve - accuracy.

Weight was measured with the aid of a mechanical scale platform with capacity of $300 \mathrm{~kg}$, and height was measured with the anthropometric ruler attached. Besides the fat percentage, BMI was also used as a final categorization of the overall nutritional status of the group ${ }^{26}$. A special attention was given to $\mathrm{AC}$ measurement, which consisted of the formula for the Arm Muscle Circumference (AMC), since it is a measurement capable to monitor the behavior of lean mass, i.e. loss or gain of muscles during harvest season $^{21}$. AMC was calculated following the formula $A M C(\mathrm{~cm})=A C(\mathrm{~cm})$ - ð $x T S(\mathrm{~cm})^{21,27}$, where TS is the value in centimeters of Triceps Skinfold. All measurements were performed on the team's day of rest.

\section{Biochemical measures}

At the end of the season, 24 of the 30 workers agreed to give a five milliliter blood sample through venipuncture, which were taken by nurses, in order to perform biochemical analysis of Creactive protein $(\mathrm{CRP})$, creatine kinase, skeletal muscle isoform (CK-MM) and plasma urea. Because of the difficult logistics in the field, it was possible to collect this sample in just one moment. Thus, we chose the end of the season in order to minimize possible exhaustion or pain where the puncture was made, as this is the greatest period of physical stress. Tests of plasma activity of CK-MM and plasma concentration of CRP were chosen for they are important biological markers, both of muscle damage and systemic and chronic inflammatory state, respectively ${ }^{28}$.

On the other hand, urea is a biomarker of metabolic stress, related to the organic level of protein degradation. This may be accentuated due to the scarce reserves of carbohydrates in the form of muscle glycogen ${ }^{28}$.

After blood samples were collected, they were properly conditioned and brought to the Clinical Laboratory of the Municipal Health Department of Piracicaba, SP to be analyzed.

\section{Questionnaire}

A questionnaire was administered orally to gather general and socio-demographic information such as date and place of birth, hometown, education, number of seasons in which they par- 
ticipated, number and time of breaks during the day, pain or cramp during cutting, water consumption, smoking-, alcohol consumption and drug use.

\section{Analysis}

The correlation between socio-demographic information such as education, age, number of previously worked harvest seasons and anthropometric data was used for data analysis.

The statistical estimation was performed using Pearson's correlation after data exploration and testing of the probability distribution of the variables involved. The comparison between observation periods in relation to anthropometric variables according to the number of harvests was performed using the Student's t- test for dependent samples or Wilcoxon test after exploitation and test of probabilistic distribution of the variables involved. As a rule of decision, the estimated effects were considered significant when $\mathrm{p}<0.05$.

The study was approved by the Ethics Committee of the Faculty of Medical Sciences, State University of Campinas.

\section{Results}

Of the 40 interviewed workers, 10 dropped out of the labor contract during the season returning to their hometowns. This loss was explained by colleagues as withdrawal by exacerbated physical fatigue, which can already be a demonstration of initial inability to continue in an activity that is too exhausting. The 30 workers who resisted until the end of the season were male, mean age corresponding to 27 years, ranging between 18 and 44 years (Standard Deviation $=6.9$ years $)$ and had an average education of 5 years (Standard Deviation $=2.7$ ). The socio-demographic data analyzed are shown in Table 1. Only five employees were starting to work with sugarcane cutting in the State of São Paulo, while 11 had worked in more than four seasons before.

When asked about the presence of any pain or cramps during the cutting activity and the part of the body affected -, the ones most cited by the 17 workers who answered yes were, respectively, legs and backs (11), abdomen (4), calf (3), arm and neck (2), and wrist, hand and head (1). Only one worker reported using body pain-relief drugs at the time of the interview.

The entire interviewed group reported consuming at least 5 liters of water during the work-
Table 1. Social-demographic and historical data on sugarcane harvesters during seasons. Piracicaba, SP, Brazil $(n=30)$.

\begin{tabular}{|c|c|c|}
\hline Variable & $\mathbf{N}$ & Proportion (\%) \\
\hline \multicolumn{3}{|l|}{ Age (years) } \\
\hline 18 to 24 & 13 & 43 \\
\hline 25 to 34 & 13 & 43 \\
\hline 35 to 44 & 4 & 13 \\
\hline \multicolumn{3}{|l|}{ Education (years) } \\
\hline 0 to 4 & 16 & 53 \\
\hline 5 to 8 & 13 & 43 \\
\hline$>9$ & 1 & 3 \\
\hline \multicolumn{3}{|c|}{ No of intervals (breaks) } \\
\hline 2 & 3 & 10 \\
\hline 3 & 10 & 33 \\
\hline 4 & 8 & 27 \\
\hline 5 & 5 & 17 \\
\hline 6 & 3 & 10 \\
\hline 7 & 1 & 3 \\
\hline \multicolumn{3}{|c|}{ Break duration (min) } \\
\hline 5 & 12 & 40 \\
\hline 10 & 17 & 57 \\
\hline 30 & 1 & 3 \\
\hline \multicolumn{3}{|c|}{ No of the harvest season } \\
\hline $1^{\text {st }}$ or $2^{\text {nd }}$ & 8 & 27 \\
\hline $3^{\text {rd }}$ to $5^{\text {th }}$ & 17 & 57 \\
\hline $6^{\text {th }}$ or more & 5 & 17 \\
\hline \multicolumn{3}{|c|}{ Pain or cramp at work } \\
\hline Yes & 17 & 57 \\
\hline No & 13 & 43 \\
\hline \multicolumn{3}{|l|}{ Smoking } \\
\hline Yes & 2 & 7 \\
\hline No & 28 & 93 \\
\hline \multicolumn{3}{|l|}{ Alcohol } \\
\hline Yes & 17 & 57 \\
\hline No & 13 & 43 \\
\hline
\end{tabular}

day, regardless of the time of the year. This intake can vary by up to 10 liters, depending on the amount of stress and temperature, which was also observed by the team while in the field. This measure was easily taken since all workers have, as part of their daily equipment, a 5-liter gallon, where water is easily replaced by water kept on the bus when necessary and they are brought from home already full.

Regarding the number of breaks and their duration, also shown in Table 1, it is noteworthy that these values $\dagger$ are an average of those breaks that were retrospectively collected in a cross-sectional manner throughout the harvest season, which may vary with the type of sugarcane and room temperature of the day. We observed - the 
breaks were taken for physiological needs, hydration, nutrition and machete sharpening.

In relation to $\mathrm{BF} \%$, the number of harvests affected significantly the fat loss in the first phase (June-September) and the harvest season as a whole (June-November) so that fat loss is greater among workers with longer history in the activity $(\mathrm{p}<0.001)$, as shown in Tables 2 and 3.

In assessing the nutritional status by BMI, one can observe an increase in its variation, in percentage, at the first stage of the harvest as the age increases. That is, the values tof weight in relation to height was significantly reduced at the first stage among older workers. This correlation observed from June to September no longer exists in the second stage of the season (Table 2). The $\% \mathrm{BF}$ showed the same relation during the first stage of the season, as shown in Table 3.

Concerning the effect of the number of seasons previously worked on - BMI, there is a significant correlation only when the entire harvest is observed, and i.e. the reduction of BMI is higher among workers with longer harvest history (Table 2). Education level showed no significant correlation on the anthropometric variations throughout the harvest.
Analyzing the effect of the number of seasons worked before the current one on variation in the AMC, there was a significant variation only in the second stage of the season (September to November). This effect was significant neither in the first stage nor during the season as a whole (Table 2). It was also observed that most workers with a history of up to four harvests gained AMC, while those who participated in more than four lost this measure (Table 3 ).

Regarding the estimate of the effect of alcohol consumption on - anthropometry, statistically significant result was only found in the percentage variation of $\% \mathrm{BF}$ in the first stage of the season, i.e., workers who reported alcohol consumption $(\mathrm{n}=17)$ had lower body fat loss than those who did not consume it $(n=13)$, respectively $-11.75 \pm 7.63$ and $-19.95 \pm 11.73(p=0.041)$.

Figure 1 confirms the loss of BMI, especially from the beginning to the middle of the harvest season $(p<0.001-$ Student's t-test for paired samples), which was also confirmed when analyzing the crop as a whole regardless of the history of the harvest, but with a smaller reduction at the second moment (September to November).

Table 2. Estimation of the socio-demographic correlation information about Body Fat Percentage (\%BF), Body Mass Index (BMI) and Arm Muscle Circumference (AMC) in the three moments of the harvest, in sugarcane harvesters. Piracicaba, SP, Brazil $(n=30)$.

\begin{tabular}{cccccc}
\hline $\begin{array}{c}\text { Anthropometric } \\
\text { variation (in \%) }\end{array}$ & Period ${ }^{(1)}$ & Education & $\begin{array}{c}\text { Age } \\
\text { years }\end{array}$ & $\begin{array}{c}\text { Number of } \\
\text { harvests }\end{array}$ \\
\hline \% BF & Jun/Sept & rho $^{(2)}$ & 0.24 & -0.28 & -0.42 \\
& Sept/Nov & $p$ & 0.205 & 0.138 & 0.021 \\
& & rho & 0.07 & -0.07 & -0.01 \\
& Jun/Nov & rho & 0.707 & 0.703 & 0.95 \\
& & $p$ & 0.27 & -0.3 & -0.39 \\
BMI & Jun/Sept & rho & 0.15 & 0.11 & 0.032 \\
& & $p$ & 0.196 & -0.45 & -0.24 \\
& Sept/Nov & rho & 0.06 & 0.013 & 0.197 \\
& & $p$ & 0.745 & 0.03 & -0.31 \\
& Jun/Nov & rho & 0.2 & -0.863 & 0.097 \\
AMC & Jun/Sept & rho & 0.282 & 0.23 & -0.45 \\
& & $p$ & 0.23 & -0.1 & 0.014 \\
& Sept/Nov & rho & 0.227 & 0.38 & 0.03 \\
& & $p$ & 0.072 & -0.33 & 0.863 \\
& Jun/Nov & rho & 0.41 & 0.074 & -0.51 \\
& & $p$ & 0.025 & -0.31 & 0.004 \\
& & & 0.092 & -0.34 \\
& & & & 0.068 \\
\hline
\end{tabular}

(1) Jun / Sept: first harvest phase; Sept / Nov: second harvest phase; Jun / Nov: complete harvest. Estimate of the Pearson's correlation coefficient 
Table 3. Comparison between the three observation periods of the harvest for Arm Muscle Circumference (AMC), Body Mass Index (BMI) and Body Fat Percentage (\%BF), in sugarcane harvesters. Piracicaba, SP, Brazil $(n=30)$.

\begin{tabular}{|c|c|c|c|c|}
\hline \multirow{2}{*}{$\begin{array}{c}\text { Anthropometric } \\
\text { Measurement }\end{array}$} & \multirow{2}{*}{$\begin{array}{c}\text { Number of harvest } \\
\text { and } n\end{array}$} & \multicolumn{2}{|c|}{ Harvest months/values } & \multirow[t]{2}{*}{$p^{*}$} \\
\hline & & June & September & \\
\hline & Up to $4(n=19)$ & $15.11 \pm 0.86$ & $12.99 \pm 0.6213 .31 \pm$ & $<0.001$ \\
\hline & Over $4(n=11)$ & $17.22 \pm 1.24$ & 0.53 & 0.004 \\
\hline & & September & November & \\
\hline & Up to $4(n=19)$ & $12.99 \pm 0.62$ & $13.07 \pm 0.73$ & 0.799 \\
\hline & Over $4(n=11)$ & $13.31 \pm 0.53$ & $13.20 \pm 0.64$ & 0.626 \\
\hline & & June & November & \\
\hline & Up to $4(n=19)$ & $15.11 \pm 0.86$ & $13.07 \pm 0.73$ & $<0.001$ \\
\hline & Over $4(n=11)$ & $17.22 \pm 1.24$ & $13.20 \pm 0.64$ & 0.002 \\
\hline \multirow[t]{7}{*}{ BMI } & & June & September & \\
\hline & $n=30$ & $23.56 \pm 0.39$ & $22.75 \pm 0.35$ & $<0.001$ \\
\hline & & September & November & \\
\hline & $n=30$ & $22.75 \pm 0.35$ & $22.80 \pm 0.39$ & 0.753 \\
\hline & & June & November & \\
\hline & Up to $4(n=19)$ & $23.27 \pm 0.52$ & $22.83 \pm 0.56$ & 0.036 \\
\hline & Over $4(n=11)$ & $24.06 \pm 0.56$ & $22.74 \pm 0.38$ & $<0.001$ \\
\hline \multirow[t]{7}{*}{ AMC } & & June & September & \\
\hline & $n=30$ & $26.14 \pm 0.24$ & $26.87 \pm 0.25$ & $<0.001$ \\
\hline & & September & November & \\
\hline & Up to $4(n=19)$ & $26.86(26.29 ; 27.86)$ & $27.41(26.11 ; 28.51)$ & $0.007^{* *}$ \\
\hline & Over $4(n=11)$ & $26.57(25.81 ; 27.67)$ & $25.93(25.48 ; 27.80)$ & $0.333^{* *}$ \\
\hline & & June & November & \\
\hline & $n=30$ & $26.14 \pm 0.24$ & $27.06 \pm 0.28$ & $<0.001$ \\
\hline
\end{tabular}

$p^{*}$ Student's $t$ test for dependent samples. Written summary of mean and standard error. $p^{* *}$ Wilcoxon $t$ test for dependent samples. Descriptive summary of median and quartiles.

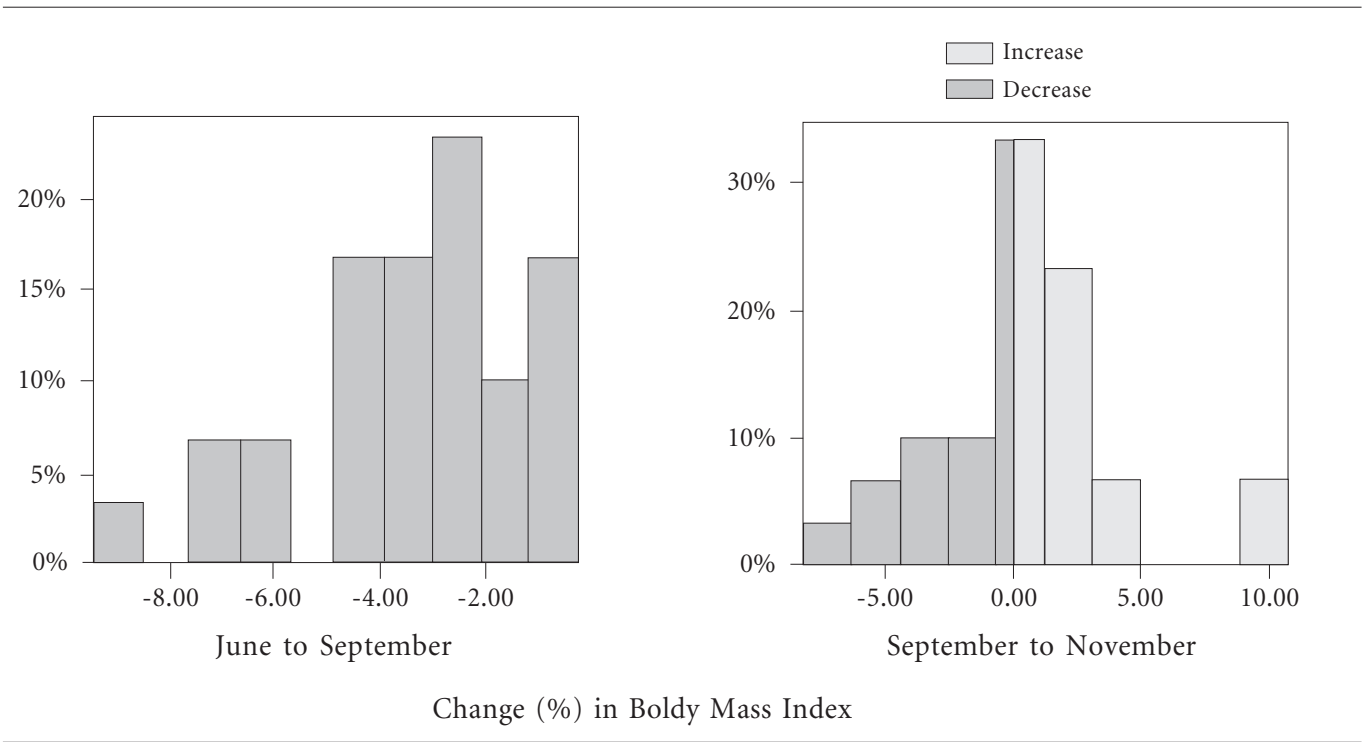

Figure 1. Change percentage (\%) in Body Mass Index of sugarcane harvesters in different periods of the harvest. Piracicaba, SP, Brazil $(\mathrm{n}=30)$. 
Table 4 presents a high frequency of changes in the indicator CK-MM, as 18 out of 24 workers from the group exceeded the reference values.

\section{Discussion}

There are no prospective anthropometric studies with these groups of workers yet, making it difficult to compare results with other workers in manual sugarcane harvesting.

The low frequency of breaks for hydration, rest and feed in this group should be evaluated carefully, considering the high temperatures in Brazil and the type of job to which they are exposed.

Concerning - education, many studies indicate that the higher the educational level, -the greater the protection against diseases or health risks ${ }^{29-31}$. In this study, the education of workers showed no significant correlation to anthropometric variables, which may suggest that for this type of work, where payment is made according to production, no matter how educated these workers are, they are unable to develop defense strategies against physical exhaustion.

Regarding - anthropometric variables, there was greater weight and body fat loss, respectively assessed by BMI and \%BF, until the middle of the harvest season, which suggests that the body, when exposed to a new stress condition, attempts to find a new anthropometric "set point", which is kept from thereafter ${ }^{22}$, associated with a more pleasant temperature - compared to other

Table 4. Biochemical tests performed at the end of the harvest with sugarcane harvesters, according to compliance and change in relation to the reference values. Piracicaba, SP, Brazil $(n=24)$.

\begin{tabular}{lcc}
\hline \multicolumn{1}{c}{ Variable } & Frequency & Percentage (\%) \\
\hline CK (U/L) & & \\
Appropriate (up to 195) & 6 & 25 \\
Changed (> 195) & 18 & 75 \\
Plasmatic urea (mg/dl) & & \\
$\quad$ Appropriate (between 15 & 20 & 83 \\
and 40) & & \\
Changed $(>41)$ & 4 & 17 \\
CRP (mg/l) & & \\
Appropriate $(<10)$ & 24 & 100 \\
Changed $(>40)$ & 0 & 0 \\
\hline
\end{tabular}

${ }^{*} \mathrm{CK}(\mathrm{U} / \mathrm{L})=$ Creatine Kinase measured in Units per Liter; ${ }^{*}$ Plasmatic urea $(\mathrm{mg} / \mathrm{dl})=$ measured in miligrams/deciliter; ${ }^{* * *} \mathrm{CRP}$ $(\mathrm{mg} / \mathrm{L})=$ C-reative protein measured in miligrams $/$ Liter months of the year, until September, when winter ends in Brazil. Along with these factors, the physical and psychological stimuli is further increased from the beginning to the middle of the season, since fatigue and high temperatures are again inherent to the second stage of the season, until December, when it is summer in the country. Those harvesters who are more experienced in this activity had gained less AMC, which could be expected since they are older and more worn out than starters in this activity. The aging process is related to loss of lean body mass and thus to the loss of this measure ${ }^{27}$.

The non-abusive alcohol consumption may be related to lower body fat loss due to its caloric values, providing additional energy to workers who consume it. Alcohol provides 7.1 kilocalories per gram $(\mathrm{Kcal} / \mathrm{g})$ ingested, thus being considered a nutrient, whereas carbohydrate and protein provide $4 \mathrm{Kcal} / \mathrm{g}$ and $9 \mathrm{Kcal} / \mathrm{g}^{32,33}$ of lipids. The biochemical measures had been expected, mainly the increased plasma activity of CK$\mathrm{MM}$, for most of the workers, considering the studied population, with profile of physical exhaustion similar to those of trained athletes ${ }^{23}$. In athletes, this enzyme generally has higher resting values that increase even more with training, especially in periods of competition ${ }^{34}$, which could not be evaluated in this group due to the lack of representative values regarding the resting condition at the beginning of the harvest season, as reported in the methodology.

Even taking into account the relevance of the results indicated by this study, it could not fail to point out some limitations that permeate it.

The first is the intentional sample design into a single group of workers because of the virtual impossibility of obtaining permission to access the fields where harvesters work. The second was the withdrawal of ten out of forty workers that started the harvest, which limits the severity of the changes found to the most resistant ones. The dropouts were possibly of the most fragile or the ones who suffered injuries that prevented their stay in the field, and their physical and biochemical changes would worsen the results. Probably few studies will be carried out under the same conditions and certainly none will be conducted in the field with a random sample representative of the population of cane cutters while the harvesting methods and the manner of employing workforce continue as they were available in Brazil by 2010. Instead, work conditions and research in the field may be aggravated by the expansion of planting for agro-energetic purpose. 
The aggravating consideration on these findings, which should be further cross-sectionally investigated, is the reduced number of breaks both during the working sessions and between sessions. This disfavors the recovery of musclejoint micro damages, which may be, in medium and long term, harmful to the physical integrity of employees ${ }^{16,34}$. Once more it becomes clear that remuneration per production, as well as the pressure on athletes to win, both physical and psychological requirements may cause severe physical and nutritional problems, and may be one of the contributors to the deaths from this group of workers.

\section{Conclusion}

This study allowed observing and measuring the work, which during the sugarcane harvest produces significant weight and body fat loss, especially in the first harvest season. This loss was even more pronounced in migrants with the largest number of seasons worked previously. The work may cause a slight increase in muscle mass

\section{Collaborations}

The first draft was written by VG Luz. The entire data collection was carried out by EF Laat, AJN Silva and VG Luz, as well as interpretation of findings. FOC Silva and LTO Zangirolani developed the instrument design. RAG Vilela and HR Corrêa-Filho contributed to article writing and reviewing. All authors contributed to the article's conceptual framework, the interpretation of the material, and the final draft.

\section{Acknowledgents}

The authors acknowledge CAPES Foundation for the master scholarship granted, Supporting Foundation for the Research of São Paulo (FAPESP) for the financial support to the research and Dr. Hélio Rubens Nunes for support in statistical analysis. (lean), which occurred in a smaller scale with more experienced workers.

These losses may indicate an accelerated wearout of this population due to the work process and payment conditions, which prevents the adoption of breaks and regulation of workloads, stimulating the exacerbation of physical overload and predisposing workers to permanent musclejoint injury. In addition to that, thermal and environmental conditions come to this picture as aggravating factors.

Biochemical data, although measured at only one moment, can be another indicator, along with other factors assessed in this work, of important physical weariness. In order to understand the behavior of biological processes resulting from this unbalanced relationship between stimulus and recovery, especially those related to chronic and systemic inflammation, further studies are needed, arising from longitudinal studies of representative samples of population. Besides that, new studies will be vital to better clarify the medium and long term effects of this type of work on health and social welfare of these workers, since this work will still be present for many years in Brazil.

\section{References}

1. Blottnitz H, Curran MA. A review of assessments conducted on bio-ethanol as a transportation fuel from a net energy, greenhouse gas, and environmental life cycle perspective. J Clean Prod 2007; 15(7): 607-619.

2. Instituto Brasileiro de Geografia e Estatística (IBGE); 2011. Municipal Agricultural Production 2007. [serial on the Internet]. [accessed 2012 Sep 7]. Available at: http://www.ibge.gov.br/english/presidencia/ noticias/noticia_visualiza.php?id_noticia $=12908$ \&id - pagina $=1$.

3. União da Indústria de Cana de Açúcar (Unica). [Sugarcane Industry Association]. (2011). Ethanol Production in Brazil. [serial on the Internet]. [accessed 2012 Sep 7]. Available at: http://english. unica.com.br/dadosCotacao/estatistica/

4. United States Energy Information Administration (EIA). (2011). Independent Statistics \& Analysis U.S. Energy Information Administration. Ethanol overview. [serial on the Internet]. [accessed 2012 Sep 7]. Available at: http://www.eia.doe.gov/mer/pdf/ pages/sec10_7.pdf

5. Santos CT, Favaro F, Parente V. [Forecast of production of flex fuel cars and ethanol demand in Brazil in 2014]. Future Studies Research Journal 2010; 2(3):85-98. 
6. Banco Nacional de Desenvolvimento Econômico e Social (BNDES), Centro de Gestão e Estudos Estratégicos (CGEE). (2008). Bioetanol de cana de açúcar: energia para o desenvolvimento sustentável. Rio de Janeiro: BNDES, CGEE; 2008. [serial on the Internet]. [accessed 2012 Sep 7]. Available at: http://www. bioetanoldecana.org/pt/download/bioetanol.pdf

7. Associação Nacional dos Fabricantes de Veículos Automotores (Anfavea). [Brazilian automotive industry yearbook] 2009. [serial on the Internet]. [accessed 2012 Sep 7]. Available at: http://www.anfavea. com.br/anuario2009/indice.pdf

8. União da Indústria da Cana de Açúcar (ÚNICA). [Sugarcane Industry Association]. Exportação brasileira de etanol por país de destino. 2011. [serial on the Internet]. [accessed 2012 Sep 7]. Available at: http:// www.unica.com.br/dadosCotacao/estatistica/

9. Alessi NP, Navarro VL. [Health and work in rural areas: sugar cane plantation workers in Ribeirão Preto, São Paulo, Brazil]. Cad Saude Publica 1997; 13(Supl. 2):111-121.

10. Oliveira F. In: Alves FJC, Novaes JR. Migrantes: Trabalho e trabalhadores no Complexo Agroindustrial Canavieiro (os heróis do agronegócio brasileiro). São Carlos: EdUFCar; 2007.

11. Alves FJC. Migração de trabalhadores rurais do Maranhão e do Piauí para o corte de cana em São Paulo: será este um fenômeno casual ou recorrente da estratégia empresarial do Complexo Agroindustrial Canavieiro? In: Alves FJC, Novaes JR, organizadores. Migrantes: Trabalho e trabalhadores no Complexo Agroindustrial Canavieiro (os heróis do agronegócio brasileiro). São Carlos: EdUFCar; 2007. p. 21-54.

12. Alves FJC. [Why are the sugar cane harvesters dying?] Saúde Soc 2006; 15(3):90-98.

13. Laat EF, Vilela RAG, Silva AJN, Luz VG. [Impact over the worn conditions: physical wear of sugarcane cutters]. In: Impactos da Indústria Canavieira no Brasil. Rio de Janeiro: Plataforma BNDES; 2008. p. 36-46.

14. Goldemberg J, Coelho ST, Guardabassi P. The sustainability of ethanol production from sugarcane. Energy Policy 2008; 36(6):2086-2097.

15. Anderson VP. Cumulative trauma disorders: a manual for musculoskeletal diseases of the upper limbs. National Institute for Occupational Safety and Health (NIOSH). Cincinnati: Taylor \& Francis; 1988.

16. Clementson CL, Hansen AC. Pilot Study of Manual Sugarcane Harvesting Using Biomechanical Analysis. Journal of Agricultural Safety and Health 2008; 14(3):309-320.

17. Teixeira MLP, Freitas RMV. Acidentes do Trabalho Rural no Interior Paulista. São Paulo Perspec 2003; 17(2):81-90.

18. Brasil. Ministério do Trabalho. Norma Regulamentadora No 3.214 de 8 de junho de 1978. Atividades e operações insalubres. Diário Oficial da União 1978; 6 jul.

19. American Conference of Governmental Industrial Hygienists (AGIH). Limites de Exposição para substâncias químicas e agentes físicos. Washington: ACGIH; 1999.

20. São Paulo. Lei No 11.241 de 19 de setembro de 2002. Dispõe sobre a eliminação gradativa da queima da palha da cana-de-açúcar e dá providências correlatas. Diário Oficial do Estado 2002; 20 set.
21. World Health Organization (WHO). Physical status: the use and interpretation of anthropometry. Report of a WHO Expert Committee. World Health Organ Tech Rep Ser 1995; 854:1-452.

22. McArdle WD, Katch FI, Katch VL. Fisiologia do Exercício: energia, nutrição e desempenho humano. 6a edição. Rio de Janeiro, RJ: Guanabara Koogan; 2008.

23. Lazarim FL, Antunes-Neto JMF, Silva FOC, Nunes LA, Bassini-Cameron A, Cameron LC, Alves AA, Brenzikofer R, de Macedo DV. The upper values of plasma creatine kinase of professional soccer players during the Brazilian National Championship. J Sci Med Sport 2009; 12(1):85-90.

24. Petroski EL. Equações Antropométricas: subsídios para uso no estudo da composição corporal. In: Petroski EL, organizador. Antropometria: Técnicas e Padronizações. 2a edição. Porto Alegre: Palotti; 2003. p. 107-125.

25. Costa RF. Composição Corporal: teoria e prática da avaliação. $1^{\text {a }}$ edição. São Paulo: Manole; 2001.

26. Anjos LA. [Body mass index as a tool in the nutritional assessment of adults: a review]. Rev Saude Publica 1992; 26(6):431-436.

27. Burr ML, Phillips KM. Anthropometric norms in the elderly. Br J Nutr 1984; 51(2):165-169.

28. Warren GL, O'Farrell L, Rogers KR, Billings KM, Sayers SP, Clarkson PM. CK-MM autoantibodies: prevalence, immune complexes, and effect on $\mathrm{CK}$ clearance. Muscle Nerve 2006; 34(3):335-346.

29. Kunst AE, Mackenbach JP. The Size of Mortality Differences Associated with Educational Level in Nine Industrialized Countries. Am J Publ Health 1994; 84(6):932-937.

30. Regidor E, Barrio G, de la Fuente L, Domingo A, Rodriguez C, Alonso J. Association between educational level and health related quality of life in Spanish adults. J Epidemiol Community Health 1999; 53(2):75-82.

31. Santos IS, Duarte EC. Fatores de risco e proteção para doenças crônicas não transmissíveis na população adulta brasileira. Rev Saude Publica 2009; 43(Supl. 2):5-6.

32. Kachani AT, Brasiliano S, Hochgraf PB. The impact of alcohol consumption on weight gain. Rev Psiq Clin 2008; 35(Supl. 1):21-24.

33. Vadstrup ES, Petersen L, Sørensen TIA, Grønbaek M. Waist circumference in relation to history of amount and type of alcohol: results from the Copenhagen City Heart Study. Int J Obes 2003; 27(2):238246.

34. Knifis FW, Santos LC, Corrêa CA, Albuquerque AC, Fernandes Filho J, Dantas EHM. [Anthropometric characteristics and relationship with exercise induced micro-injuries]. Braz J Biomotricity 2008; 2(2):122-131.

Artigo apresentado em 05/07/2011

Aprovado em 10/10/2011

Versão final aprovada em 04/11/2011 